\title{
Sexual Harassment and the Real North Country: Revelations of an Expert Witness
}

\author{
Deborah Erdos Knapp ${ }^{1}$ (D)
}

Published online: 1 October 2015

(C) Springer Science+Business Media New York 2015

In the film North Country, Academy-Award-winning-actress Charlize Theron portrays Josey Aimes, one of many female miners in Eveleth, Minnesota subjected to a wide range of injurious and abusive sexual behaviors by male coworkers. Moreover, the behaviors were tacitly condoned by company management. The women portrayed in the film became part of the first successful class action suit brought against an employer because of sexual harassment (Jenson vs. Eveleth Taconite Company 1991).

Since Jensen, many U.S. organizations and managers have traveled great philosophical distances and have acquired the ethical and intellectual heft to avoid the type of rampant behaviors that caused Eveleth Mines (located in Eveleth, Minnesota, U.S.) to lose the lawsuit. Unfortunately, we may not have traveled as far as we think. As an expert witness in the area of sexual harassment, I continue to be flummoxed and amazed each time I am faced with reports, depositions, and testimony concerning the actions of employees in organizations today. According to the combined data of the U.S. Equal Employment Opportunity Commission (EEOC) and Fair Employment Practices agencies (FEPAs), in 2011 approximately 11,364 sexual harassment complaints were filed resulting in $\$ 53.2$ million in monetary benefits paid to complainants by offending organizations (EEOC 2015a). From 2010 to 2014, the EEOC alone received 37,442 SH complaints with $\$ 208.9$ million in monetary benefits paid to complainants (these values do not include monies obtained through litigation (EEOC 2015b)). Even in our post-modern, sophisticated, well-trained, and well-educated world, individuals, groups, and organizations continue to astonish and disturb us with reports of undesirable sexual behavior.

Why does sexual harassment continue to afflict organizations and individuals with such persistence? We are all aware of the risks — both personal and professional — of engaging in behavior that benefits no one and in fact, can injure others. Why does it continue? Is it that we make mistakes in selecting individuals into our organizations and then promoting them into positions of power? Is it an organizational problem? Is it primarily a gender-based issue? I

Deborah Erdos Knapp

dknapp1@kent.edu

1 Department of Management and Information Systems, College of Business Administration, Kent State University, Kent, OH 44242, USA 
examine the possible answers to these questions by integrating the scientific knowledge concerning sexual harassment with illustrations from an actual case ${ }^{1}$ in which I served as an expert witness (the case was chosen as it included the most noxious behaviors I have encountered). Implications for policies, procedures, and training are also discussed.

\section{Where and why does it Happen? The Scientific Evidence on Organizational Tolerance for Sexual Harassment}

A number of factors increase the probability of organizational tolerance for sexual harassment, which contributes to the development and maintenance of sexually hostile work environments (the EEOC (1998) defines hostile environment sexual harassment as “...verbal or physical conduct of a sexual nature... [that] has the purpose or effect of unreasonably interfering with an individual's work performance or creates an intimidating, hostile, or offensive work environment" [184]). These include: (1) the organizational climate; (2) the organization's leadership; (3) the gender composition of the workforce; (4) the "pioneer status" of the employee; and (5) the sexual-harassment-related policies, procedures, and practices of the organization.

Organizational Climate Organizational climate is defined as the shared perceptions of employees concerning the policies, procedures, and practices of their organization (Offerman and Malamut 2002; Schneider 1990). Sexual harassment is a social construct and as such, is governed not only by individual propensities, but also by the organizational climate and its tolerance for sexual harassment. Numerous studies demonstrate that organizational climates tolerant of sexual harassment are characterized by a number of factors: (a) highly sexualized work environments; (b) employee perceptions that perpetrators of sexual harassment will not be punished; and (c) an increased probability that reports of sexual harassment will meet with retaliation (e.g., Bowes-Sperry and O'Leary-Kelly 2005; Cortina et al. 2002; Cortina and Wasti 2005; Hulin et al. 1996; O’Leary-Kelly et al. 2009). Further, such environments have the effect of tacitly condoning such behavior, which can have a disinhibiting effect on individuals who are likely to harass (Gettman and Gelfand 2007; Hershcovis and Barling 2010; Mellon 2013). Alternatively, organizational norms that prohibit such behavior dissuade individuals with a propensity to engage in sexually harassing behavior (Gettman and Gelfand 2007; Krings and Facchin 2009; Lim and Cortina 2005; Mellon 2013; O’Leary-Kelly et al. 2009). In their meta-analysis of the antecedents and consequences of sexual harassment, Willness et al. (2007) found organizational climate to be the best predictor of the whether hostile environment sexual harassment persists in an organization. Clearly, sexual harassment does not occur in a vacuum but in an organizational environment that affects the way people behave. If the organization's climate tolerates sexual harassment, the severity and frequency with which those behaviors occur is likely to increase and retaliation against individuals that report sexual harassment is likely to be the norm.

Organizational Leadership According to the academic research, the perceived attitudes of an organization's leadership influence the organizational climate regarding sexual

\footnotetext{
${ }^{1}$ Identifying information concerning incidents of sexual harassment has been changed to protect the anonymity of the parties involved.
} 
harassment (Firestone and Harris 2003; Lim and Cortina 2005; Offerman and Malamut 2002; O’Leary-Kelly et al. 2009). Additionally, formal policies and values may differ significantly from actual practice if the leadership does not support the espoused policies and values of the organization (Schein 1992). Hence, if the leadership of an organization is reluctant to view sexual harassment as a serious work-related problem and does not appear to support the related policies and procedures, the severity and frequency of sexual harassment will likely increase and targets will be less likely to report their experiences (Fitzgerald et al. 1997; Knapp et al. 1997; Popovich 1988). Additionally, the manner in which executives and managers behave when sexual harassment charges are brought affects the subsequent behavior of both targets and perpetrators and the climate of the work group in general (Firestone and Harris 2003; Offermann and Malamut 2002; O'Leary-Kelly et al. 2009).

Research has also shown that the attitude of an immediate supervisor/manager has a similar effect on the organizational climate of the work group and in turn, influences the behavior of subordinates regarding sexual harassment. For example, supervisors who encourage (or do not discourage) sexual harassment are not approachable by a target of sexual harassment and therefore, the behavior goes unreported (Offerman and Malamut 2002).

As organizational climate and leadership are inextricably linked, when leaders engage in sexually harassing behavior, the impact of their actions reverberates throughout the organization. If a sexual harassment policy is to be successful, the organization's leadership must demonstrate unyielding support for the policy. In fact, leaders' efforts to implement and enforce sexual harassment policies have an impact beyond the presence of the policies themselves (Offerman and Malamut 2002). Therefore, when a leader violates an organization's sexual harassment policy, the target of the behavior is not the only casualty. The organization's climate concerning sexual harassment is affected negatively as well, which may have a chilling effect on the reporting behavior of targets (Knapp et al. 1997).

Incidents described below from a case in which I was involved illustrate how leaders affected the organization's climate, leading to several disturbing incidents of sexual harassment. The organization (hereafter referred to as "The Service Company") is considered an industry leader and one of the largest organizations of its kind.

Vice President Turner, legal counsel for the organization and a sexual harassment trainer, epitomized the harassment-laden climate at The Service Company. First, he engaged in many reported acts of sexual harassment. For example, while inebriated at a company-sponsored event, he removed his trousers in full view of employees and clients. Although the act was witnessed and substantiated by many witnesses, Mr. Turner denied the allegation, so his superior (General Counsel for The Service Company, Mr. Brown) dismissed the report as untrue and ended the investigation. The Service Company's response to this behavior (and many other acts of Mr. Turner) no doubt had a dispiriting effect on employees' beliefs that their reports of sexual harassment would be taken seriously by the organization.

Moreover, in his statement Mr. Turner repeatedly asserted that judgments as to whether his behaviors (too numerous to be recounted here) rose to the level of sexual harassment turned on whether his targets were offended. Mr. Turner's statement is disturbing on many levels. First, a harasser is unlikely to know in advance if a prospective target will be offended by his or her (the harasser's) behavior. Second, most targets, even if they are offended, do not confront the harasser or report the behavior, particularly if the perpetrator is someone in a position of power, 
such as Mr. Turner. Third, he could not have known if a bystander was offended by his behavior. Finally, as legal counsel and a sexual harassment trainer, Mr. Turner should have known what behaviors rise to the level of actionable sexual harassment. In fact, given his position at The Service Company, Mr. Turner had an affirmative obligation to prevent and stop sexually harassing behavior when he encountered it. Instead, he regularly engaged in acts of sexual harassment.

Perhaps most troubling is that Mr. Turner continued as a sexual harassment trainer long after many of his actions were brought to light. By allowing Mr. Turner to continue training employees on the issue of sexual harassment, the leadership of The Service Company sent a clear message to its employees - sexual harassment is tolerated at the highest reaches of company management.

Gender Composition of Work Group Scientific evidence suggests that the gender composition of an individual's work group will affect the frequency and severity with which sexual harassment occurs. Individuals in sex-skewed work environments (particularly women in male-dominated work environments) are more likely to experience sexual harassment at work (Bergman 2008; Langhout, et al. 2005; Lim and Cortina 2005; O’Leary-Kelly et al. 2009; Raver and Gelfand 2005; Raver and Nishii 2010; Bitton and Shaul 2013).

As might be expected, the presence of women in many male-dominated organizations has disturbed the norms and behaviors to which many of the male employees have become accustomed. For example, at one time, a salesman might entertain a client at a "gentleman's club." Today, many coworkers and clients are women, and men accustomed to using such tactics find these traditional tools prohibited-and resent it. Hence, the response of some men to the presence of women has been to create an atmosphere of intimidation and hostility toward women (Krings and Facchin 2009; Mellon 2013). Further, as many women assume they will not be believed or supported if they report these behaviors, the strategies of these male employees often succeed in that much of the behavior goes unreported (Knapp et al. 1997).

The Service Company's workforce included significant gender-based occupational segregation (most managers were men and nearly all the support staff were women) along with a generally sex-skewed employee environment (i.e., the ratio of female to male employees was small) that contributed to a climate of tolerance for sexual harassment. For example, statements from many employees described frequent employee outings to strip clubs, taverns, and bars - all characteristic of gender-segregated and sex-skewed work environments. Many examples of this type of behavior were recounted by witnesses: (1) company executive Mr. Smith testified that while attending The Service Company's annual conference, he went to a gentleman's club with clients and employees; (2) Executive Vice President Jones testified that he went to a gentleman's club with a female support person; (3) in a conversation with a female support person, two managers recounted in shocking detail their trip to a strip club; (4) another female support person testified that many of the male employees went to strip clubs during lunch and upon returning would have explicit conversations about their experiences; and (5) one of The Service Company's few female managers indicated that alcoholic beverages were a central part of most firm outings and included trips to strip clubs and attendance at parties at which employees removed their clothes. For example, Senior Counsel Turner testified that he attended a topless bar with company employees, a client, and his wife; and (6) finally, a female member of the Human Resource Department (HR) indicated that she felt 
pressure to hire "eye candy" and that when she interviewed candidates, men in the office would hold up fingers rating the candidate's attractiveness. ${ }^{2}$

Pioneer Status "Occupational pioneers" or individuals in non-traditional occupations for their gender, report more social-sexual behavior at work, more sexual harassment, and are more likely to report negative consequences as a result of sexually harassing behavior than are individuals in gender-traditional occupations (Berdahl 2007a, b; Krings and Facchin 2009; Welsh and Gruber 1999). Organizations occupationally segregated by gender (i.e., women in the organization generally only hold positions that are commonly thought of as "women's work" [e.g., secretary or receptionist]) are more likely to have occupational pioneers in their workplaces.

Occupational pioneers often find that conventional sex-role norms influence the activities engaged in by employees, which may include employee gatherings at strip clubs and bars. Since women in such contexts are under strong pressure to "fit in," they often "go along" in attempts to gain acceptance by male peers (Berdahl 2007a, b; Kanter 1977; Krings and Facchin 2009). However, this "acceptance" requires participation in activities that are not appropriate or acceptable for many employees. Additionally, the behavior in such contexts often leads to increased levels of unwelcome social-sexual behavior. Female managers at The Service Company may be characterized as occupational pioneers, and hence, are likely to experience more sexual harassment and report more negative outcomes resulting from the harassment.

Consider the personal experience of one of the few female managers of The Service Company, Debbie. Debbie began to experience sexual harassment from the moment she joined the organization. As Debbie was leaving the restroom at a holiday party to which she and her husband were invited just before she began working at The Service Company, a senior manager (who was inebriated), pinned her against a wall, pressed his body against hers, and told her that he had to have her. Upset with the manner in which she was treated by this man following her rebuff of him, she recounted the holiday party incident to her supervisor. Although her supervisor had an affirmative obligation to investigate the perpetrator's sexually harassing behavior, he did not. In fact, his response was to ask Debbie to work more closely with and learn the business from the man who sexually harassed her.

Debbie was also upset because another Service Company male manager intimated to a client that she was a lesbian. When she reported this to The Service Company's Senior Counsel and sexual harassment trainer, Mr. Turner, he indicated that he could not help her because he could not prove she was not a lesbian as he (Mr. Turner) had not slept with her. In

\footnotetext{
${ }^{2}$ Organizations with similar occupational segregation and gender-skewness problems demonstrate that these types of environments are at high risk for sexually hostile environments. For example, a U.S. District Court judge gave consent for a proposed settlement in a high-profile case against Salomon Smith Barney, which included allegations that women were harassed by senior male workers in the interestingly termed "boom-boom room" of a branch office in New York. Merrill Lynch had significant problems with sexual harassment and paid hundreds of millions of dollars to settle with most of the claimants. Some Merrill Lynch female employees believe that the company has not made significant progress in addressing sexual harassment (Cummings and Cohen 2002). In yet another high-profile case in the securities industry, executives of the brokerage house First Asset Management (formally, Lew Lieberman and Co.) agreed to pay $\$ 1.75$ million to settle a government lawsuit in which top managers were accused of sexually harassing female workers and discriminating against women and blacks in raises and promotion (Weiser 1998). Finally, Morgan Stanley settled a discrimination suit (brought by the EEOC) for \$54 million. A former Morgan Stanley employee brought the complaint alleging widespread sex discrimination at the firm, including strip-club outings with clients and higher pay for men (Bobelian, 2004).
} 
this case, a Service Company employee sought relief through corporate counsel, and when she did, he harassed her.

Attempting to seek relief, Debbie sent information concerning her experiences to her district HR representative. The HR representative indicated that she would not get involved as she did not want to do anything to jeopardize her job (i.e., the representative feared harsh consequences concerning her own job). Additionally, one of Debbie's coworkers confided to Debbie that a manager often grabbed her (the co-worker), kissed her, told her he loved her, and that he wanted to be with her. When Debbie suggested that her coworker lodge a formal complaint, her coworker stated that if she complained, she feared she would lose her job. These responses are typical of targets who fear retaliation in organizations tolerant of sexual harassment.

Sexual Harassment Policies, Practices, and Procedures Policy statements that are not well-communicated and distributed, are not backed by all levels of management, and that are generally weak in their approach to sexual harassment contribute to an increased climate of tolerance for sexual harassment. This manifests itself in the form of inadequate reporting and documentation procedures, unclear investigatory procedures, and vague and imprecise sanctions for perpetrators (Jacobs and Kearns 2001; Kessler 2001; Pearce and DiLullo 2001; Stokes et al. 2000).

\section{What do Targets of Sexual Harassment do When they are Harassed? Common Responses to Sexual Harassment}

The sexual harassment literature is replete with studies that indicate most targets of sexual harassment do not make official complaints either to their organizations or to another agency (e.g., Balogh et al. 2003; Bergman et al. 2002; DuBois et al. 1999; Fitzgerald et al. 1995; Halbesleben 2009; Malamut and Offerman 2001). As shown in the Table 1, 32 years of research involving 23 studies strongly indicate that making a formal complaint is the least likely response to an incident of sexual harassment. This research raises the question, why are sexually harassing incidents largely unreported?

The choice of whether to report a harassing incident is complex (most experiences of sexual harassment are not one-time events and usually include a series of escalating behaviors over time) and is influenced by a number of variables (Bowes-Sperry and O'Leary-Kelly 2005; Cortina and Wasti 2005; Berdahl and Moore 2006; Lucero et al. 2006). Many research studies suggest that the driving force behind non-reporting is fear. Targets report that they fear they will not be believed or that their complaint will be trivialized. They also fear negative careerand personal-related implications such as long-term career damage, termination, humiliation, isolation, increased hostility from the perpetrator, the personal stress associated with lodging a complaint and its accompanying investigation, and failure to sanction offenders (Gutek and Koss 1993; Halbesleben 2009; Knapp et al. 1997; U.S. Merit Systems Protection Board [USMSPB], 1981; 1988; 1995). Other targets have indicated that they did not report the incident as they feared being labeled a troublemaker or victim (Fitzgerald et al. 1988; Koss 1990; Rabinowitz 1990).

The scientific evidence demonstrates that fear of retaliation from perpetrators, coworkers, or the organization is the overriding cause behind targets' unwillingness to report incidents of sexual harassment (Balogh et al. 2003; Bergman et al. 2002; Near et al. 2004; Sigal et al. 
Table 1 Rates of Formal Complaints of Sexual Harassment

\begin{tabular}{|c|c|c|}
\hline Sexual Harassment Study & $\begin{array}{l}\% \text { Formal } \\
\text { Complaints }\end{array}$ & Description of Sample \\
\hline U.S. Merit Systems Protection Board (1981) ${ }^{\mathrm{a}}$ & $3 \%$ & Federal government employees \\
\hline Gruber and Bjorn (1982) & $7 \%$ & $\begin{array}{l}\text { Female employees at an auto assembly } \\
\text { plant }\end{array}$ \\
\hline Adams et al. (1983) & $0 \%$ & $\begin{array}{l}\text { Female and male undergraduate/graduate } \\
\text { students }\end{array}$ \\
\hline Gutek (1985) & $18 \%$ & Private-sector workers in Los Angeles area \\
\hline Maypole (1986) & $6-7 \%$ & Social workers \\
\hline Schneider (1987) & $3 \%$ & Female graduate students \\
\hline U.S. Merit Systems Protection Board (1988) & $5 \%$ & Federal government employees \\
\hline Fitzgerald et al., (1988) & $3 \%$ & Graduate and undergraduate students \\
\hline Sandroff (1988) & $5 \%$ & Working Woman survey \\
\hline Grauerholz (1989) & $5 \%$ & Female university professors \\
\hline Martindale (1989) ${ }^{\mathrm{b}}$ & $10 \%$ & DOD employees \\
\hline Wishnietsky (1991) & $7 \%$ & High school students \\
\hline Women’s Legal Defense Fund (1991) & $1-7 \%$ & Female civilian work force \\
\hline $\begin{array}{l}\text { Los Angeles Commission on the Status of } \\
\text { Women (1992) }\end{array}$ & $2 \%$ & Protective service employees \\
\hline Sandroff and Baseman (1992) & $26 \%$ & Working Woman survey \\
\hline U.S. Merit Systems Protection Board (1995) & $12 \%$ & Federal government employees \\
\hline Gruber and Smith (1995) & $8 \%$ & Canadian women \\
\hline Bastian et al. (1996) & $24 \%$ & DOD employees \\
\hline Cochran et al. (1997) & $2 \%$ & University staff, faculty, and students \\
\hline Peirce et al. (1997) & $20 \%$ & $\begin{array}{l}\text { Managerial women from a diverse group of } \\
\text { industries }\end{array}$ \\
\hline Lipari and Lancaster (2003) & $20 \%$ & DOD employees \\
\hline Lipari et al. (2008) & $22 \% / 21 \%$ & $\begin{array}{l}\text { DOD employees (male/female reporting } \\
\text { rates) }\end{array}$ \\
\hline Defense Manpower Data Center (2013) & $19 \% / 33 \%$ & $\begin{array}{l}\text { DOD employees (male/female reporting } \\
\text { rates) }\end{array}$ \\
\hline
\end{tabular}

\footnotetext{
${ }^{\text {a }}$ The USMPB samples are stratified random samples of federal employees listed in the Central Personnel Data File of the Office of Personnel Management and include persons employed by the FBI, CIA, Federal Election Commission, U.S. Postal Service and Postal Rate Commission, NSA, Federal Reserve Board, White House Office, Tennessee Valley Authority, Department of Defense, and Veteran's Administration

${ }^{\mathrm{b}}$ The DOD samples are stratified random samples and include active-duty military personnel in the Army, Navy, Air Force, Marine Corps and Coast Guard
}

2003). Moreover, fear of retaliation is a legitimate concern for targets. In fact, not reporting incidents of sexual harassment may be a rational response to sexually oppressive workplace conditions (Bergman et al. 2002; Gutek and Koss 1993; Magley 2002; Stockdale 1998). Simply put, the potential benefits of reporting may not outweigh the risks.

The lack of reporting by targets of sexual harassment has been widely researched over many years. Hence, organizational leaders, particularly those serving in human resource and legal capacities, should be well aware of this capacity for non-reporting. Since they know that lack of reporting is not in any way indicative of a lack of a sexually hostile environment (in 
fact, the opposite may actually be true: a lack of reporting may be the result of oppressive workplace conditions and a sexually hostile environment), leaders must be particularly vigilant in assessing the organizational environment regarding sexual harassment. Additionally, they must ensure that the policies, procedures, and practices of the organization minimize these fears by taking seriously all reports of sexual harassment and guaranteeing that any retaliation against targets will be met with swift and harsh punishment.

A typology of responses to sexual harassment developed by Knapp et al. (1997) has found support in the literature (Cortina and Wasti 2005; Offerman and Malamut 2002) and illustrates the responses available to targets of sexual harassment (see Fig. 1). Building on the outcomes of previous research in response-type identification, the typology is based on the idea that responses vary with respect to two elements: focus of response and mode of response. The focus of a response to sexual harassment may be either self-focused or initiator-focused. Generally, self-focused responses are coping strategies that do not involve the perpetrator of the sexual harassment, while initiator-focused responses directly address the perpetrator and the incident.

Responses also vary with respect to the amount of outside support sought by the target. The typology identifies this dimension as mode of response and varies from self-response (the target uses no outside resources to address sexual harassment) to supported response (the target uses other individuals, organizational resources, or extra-organizational resources to address sexual harassment). The juxtaposition of the dimension of focus of response with the dimension of mode of response forms four archetypical response strategies for coping with sexual harassment: avoidance/denial, social coping, confrontation/negotiation, and advocacy-seeking.

Avoidance/denial coping responses to sexual harassment are self-focused (the perpetrator is not confronted) and involve little to no outside support. These self-focused, low-intervention strategies are used most frequently by targets of sexual harassment and are the least effective in ending the behavior (Brooks and Perot 1991; Cortina and Wasti 2005; Offerman and Malamut 2002). Targets of sexual harassment may use this response strategy as they fear retaliation from the perpetrator, coworkers, or the organization, which has been shown to be a legitimate concern (Dandekar 1990; Gutek and Koss 1993; Kremer and Marks 1992). Avoidance/denial behaviors include altering the job situation (e.g., quitting or transferring), avoiding the

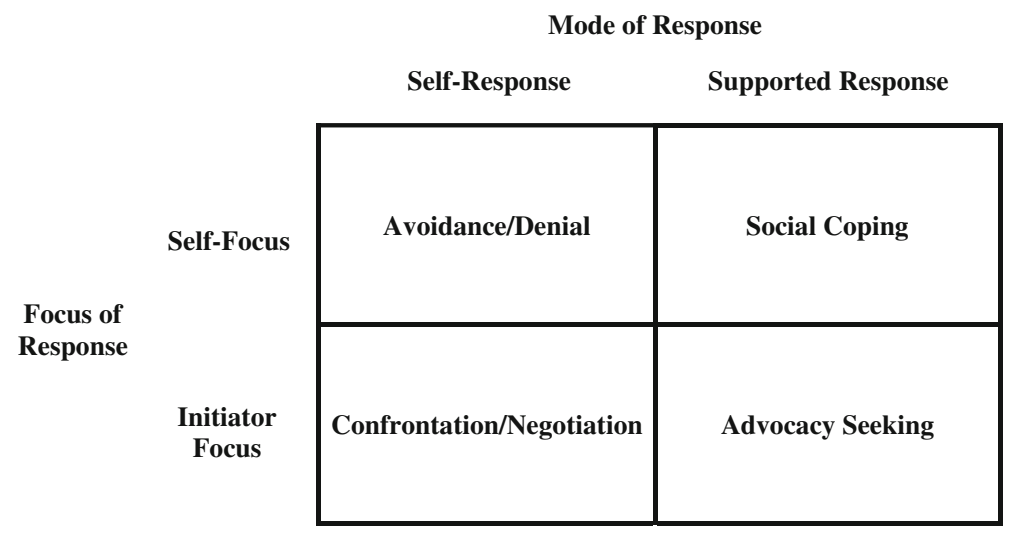

Fig. 1 Typology of Target Responses to Sexual Harassment. In Knapp, D. E., Faley, R. H., Ekeberg, S. E., \& Dubois, C. L. Z. (1997). Determinants of target responses to sexual harassment: A conceptual framework. Academy of Management Review, 22, 687-729 
perpetrator, ignoring the behavior, going along with the behavior, treating the incident(s) as a joke, self-blame (i.e., targets believe that they may have provoked the behavior), or doing nothing (Bell and Reardon 2011; Gruber 1989; Gutek 1985; Knapp et al. 1997; Watson et al. 2013).

Social coping responses also involve self-focused strategies for coping with sexual harassment (e.g., the perpetrator is not addressed directly), however it differs from avoidance/denial strategies in that the target chooses to seek support from others in addressing the harassing incident. For example, some targets of sexual harassment employ the strategy of "bringing along a friend" whenever they believe the perpetrator will be present (Gutek and Koss 1993; Hotelling 1991; Knapp et al. 1997). Other targets may discuss their experiences with sympathetic others, such as peers, coworkers, friends, and family members (Gruber 1989; Knapp et al. 1997). Unfortunately, as with other self-focused responses, this particular strategy is not effective in stopping the harassment, although it may assist the target in managing the psychological and somatic outcomes associated with the event and provide the target with suggestions for more effective coping. The use of medical or emotional counseling is also a form of social coping in that it is a self-focused response that includes the support of others. Again, while not particularly effective in ending the behavior, counseling may assist the individual in diffusing the event and finding more effective solutions to the problem.

Confrontation/negotiation includes coping responses that are negligible in terms of the use of outside support but are initiator-focused because they involve addressing the perpetrator directly. Although these responses appear to be effective in ending the behavior, they are used infrequently by targets of sexual harassment (Grauerholz 1989; Gruber 1989; Knapp et al. 1997; USMSPB 1981, 1988, 1995), generally out of fear of retaliation or a propensity to avoid conflict (Gadlin 1991; Lach and Gwartney-Gibbs 1993). In addition, these more assertive responses are associated with greater emotional distress, another explanation for the lack of initiator-focused responses (Livingston 1982). Actions that conform to the confrontation/ negotiation archetype include asking or telling the harasser to stop or threatening the harasser.

Advocacy-seeking encompasses all those responses to sexual harassment that include the use of individual or organizational support and the use of remedies that focus the response on the initiator of the behavior. Although these types of responses have been shown to be effective in ending the behavior, they are used rarely by targets of sexual harassment (Fitzgerald and Shullman 1993; Gutek and Koss 1993; Hotelling 1991). These actions would include reporting the behavior to a supervisor, an official body of the organization, contacting an outside agency, such as the EEOC, asking another person to intervene (for example, asking a friend to tell the person to stop the behavior), or seeking legal remedies through the court system. As in the case of direct confrontation, these actions are not risk-free, in that individuals that take official action may be targets of retaliation by perpetrators, coworkers, or the organization.

Although the typology categorizes individual, singular responses to sexual harassment, most targets tend to employ a sequence of coping responses in their efforts to end the unwanted sexual attention they receive (Gutek and Koss 1993; Knapp et al. 1997). The use of a constellation of responses may be the result of targets progressing sequentially through the typology from the most self-focused, low-intervention coping techniques to the more perpetrator-focused, high-intervention techniques. Methods such as confronting or reporting the harasser are typically used only after more self-focused methods have failed to end the behavior (Gruber 1989; Gutek and Koss 1993; Knapp et al. 1997). The challenge for individuals and organizations is to encourage "quadrant shifts" in the typology from least effective to more effective responses. 
Impact of Organizational Climate on Reporting Behavior As previously discussed, an organization's climate regarding sexual harassment influences the severity and frequency with which these behaviors occur. The organizational climate also influences individuals' responses to sexual harassment. Environments that tolerate sexually harassing behavior are less likely to encourage targets to report the behavior and in fact, may be inhibitory with respect to more direct responses to sexual harassment (Fitzgerald et al. 1997; Knapp et al. 1997; Magley 2002; USMSPB, 1981, 1988, 1995). In such climates individuals are likely to perceive a strong relationship between reporting sexual harassment and negative outcomes (e.g., retaliation against individuals who report sexual harassment (Brooks and Perot 1991; Offermann and Malamut 2002)). Therefore, it is not surprising that the most infrequent response to sexual harassment is to seek organizational relief (e.g., notify a supervisor or make a report to an HR professional).

Impact of Organizational Leadership on Reporting Behavior Organizational leaders at all levels can significantly influence the reporting behavior of targets of sexual harassment (Offerman and Malamut 2002). In fact, the influence of leadership behavior has an additive impact on reporting that goes beyond the organizational climate and the policies, practices, and procedures of the organization. Moreover, leadership at all levels influences the propensity to report sexually harassing behavior and affects employee satisfaction with the reporting process (Offerman and Malamut 2002). Hence, the attitudes and behaviors demonstrated by organizational leaders are important variables in predicting whether a target of sexual harassment will report the behavior.

In addition, an immediate supervisor's or manager's attitude regarding sexual harassment affects the organizational climate of the work group and in turn, influences the choice of individual coping responses to sexual harassment. As stated earlier, supervisors that encourage (or do not discourage) sexual harassment are not seen as approachable by targets of sexual harassment (Gutek and Nakamura 1982). This is particularly problematic when the supervisor is the "first line of defense" in a sexual harassment policy.

Gender Composition of the Work Group and its Influence on Reporting Behavior Sex-skewed work groups are more likely to have hostile or offensive work environments (Gutek 1985; Gutek et al. 1990; O'Farrell and Harlan 1982) and these hostile environments are likely to discourage reporting of sexual harassment. For example, based on pressures associated with their minority status (greater visibility, performance pressure, and isolation [Kanter 1977]), women in male-dominated work groups may be less likely to report sexual harassment, especially if the organization tends to be tolerant of such behavior and reporting tends to result in negative outcomes (Fitzgerald and Shullman 1993; Gruber and Smith 1995; Knapp et al. 1997).

Employees of The Service Company provided countless incidents that demonstrate how sex-skewed environments have an inhibiting effect on reporting behavior:

(1) When a female support staff employee reported that her boss grabbed her breast, the response of the HR Department was to ask the perpetrator to apologize to her. This 
woman indicated that confronting her boss frightened her, yet the HR department's solution was to put her alone in a room with the very man that had sexually assaulted her only 1 week earlier.

(2) Sue, a management support person, testified that a male manager propositioned one of her coworkers, Karen, on a regular basis. When Karen and a few of her coworkers complained about his behavior, the male manager refused to speak to Karen or the others who complained. In fact, he would use the administrative assistant to communicate with support staff. Karen feared that her performance reviews would suffer as a result of her complaint as she was a support person for this male manager. This sort of retaliation is common in organizations tolerant of sexual harassment.

(3) A female project manager testified that she left The Service Company because the behavior of two male managers created a hostile work environment for her. When she complained to her HR representative, the HR person questioned the men who in turn, complained about this female employee's work performance. As a result, the HR representative placed documentation about the incident in the female project manager's file, but placed no similar documentation in the men's files.

(4) When she quit The Service Company, support person Nicole indicated to her supervisor that sexual harassment had a part in her decision to leave. Nicole recounted an incident in which a male manager told her he would like to thrash her. When confronted about his behavior by the Vice President of HR, the perpetrator indicated that his remarks were taken out of context and that Nicole was overly sensitive. The male manager was not disciplined in any way, even though he admitted to the remark. Nicole's departure from The Service Company is not unusual: transferring or quitting is not an uncommon response for targets of sexual harassment, particularly when they perceive that their complaints will not be taken seriously or that they may experience retaliation (Faley et al. 1999; Fitzgerald et al. 1995; Knapp et al. 1997).

(5) After managerial support person Mary made a complaint of sexual harassment with The Service Company's HR Department, her position changed twice in less than a year's time. Further, although she requested training for the new and unfamiliar tasks she was required to perform as part of her new position, her requests for training were denied. Absent appropriate training, Mary was unable to succeed in her job, setting her up for failure. She was terminated after a few months in her new position.

\section{Best Practices Policies and Procedures and Their Impact on Sexual Harassment}

Following a best practices approach to sexual harassment can minimize sexually harassing events and mitigate an organization's liability. Essential elements of a best practices approach can be found in Table 2 (Jacobs and Kearns 2001; Kessler 2001; Pearce and DiLullo 2001; Remick et al. 1990; Stokes et al. 2000).

In addition to those practices listed in Table 2, an effective policy must be well-communicated, understood, and based on a solid distribution plan. The distribution plan should disseminate the policy to employees on multiple occasions which include: (a) an initial distribution at the time of hiring (with signed acknowledgement from the employee that the 
Table 2 Essential Elements of a Best Practices Approach to Sexual Harassment Policies and Procedures

1. An unequivocal statement of the organization's principles and values concerning sexual harassment.

2. A synopsis of federal, state, and local laws (where applicable) regarding sexual harassment, including examples of prohibited behavior.

3. An explanation of who is protected by the sexual harassment policy and what persons may constitute perpetrators (e.g., employees, clients, bystanders).

4. A description of managerial responsibilities regarding sexual harassment.

5. Clearly defined sanctions and disciplinary procedures for perpetrators of sexual harassment, including a detailed and graduated disciplinary system based on frequency or severity of sexual harassment.

6. Provisions for effective reporting options, including victim assistance programs.

7. Clearly defined investigatory procedures including the identification of those individuals with the authority and qualifications to conduct such investigations and training for said investigators.

8. Clear and demonstrated management support for the policies, procedures, and practices related to sexual harassment.

9. Protection of the privacy and anonymity of the involved parties.

10. Guarantees against target retaliation as a result of reporting or resisting sexual harassment and clearly defined sanctions against those who engage in retaliation.

11. Monitoring of the environment following disciplinary actions to ensure that the actions have been effective in halting the harassment.

12. Guarantees for prompt action when sexual harassment occurs.

13. Strict documentation procedures.

14. Sexual harassment training for all new employees and recurring training that emphasizes the organization's commitment to eradicating sexual harassment.

15. Regular administration of sexual harassment surveys or audits to identify problems and take appropriate action when problems are discovered.

policy was received, read, and understood); and (b) periodic redistributions that may occur during performance reviews, in company newsletters, during periodic training, or at the start of a new year. (Pearce and DiLullo 2001).

Unfortunately, many organizations do not adhere to best practices sexual harassment policies and procedures, with predictable consequences. For example, at the Service Company, the policy was not well-communicated, was rarely distributed, and was buried in a large manual. At the time of my analysis of the case, more than a dozen different versions were identified, all with different reporting instructions. Additionally, the company had not analyzed exit interviews of employees in order to determine the extent to which sexual harassment led to their departure. Moreover, many of the company's leaders (most disturbingly those in the HR department), were not particularly knowledgeable about its sexual harassment policy (e.g., the Director of HR indicated that she believed documentation was an element of The Service Company's sexual harassment policy when in fact, the policy mentioned nothing concerning documentation). Many examples of the company's lack of adequate sexual harassment policies and procedures were evident in the statements of employees:

(1) One HR representative, whose duty it was to enforce and investigate incidents of sexual harassment, was clearly confused concerning the issue of sexual harassment. First, she indicated that it was not against The Service Company's sexual harassment policy to share sexual experiences with coworkers. In fact, when asked if she understood how an employee might find these types of discussions offensive, she said, "No." 
(2) This same HR representative said that if a former employee complained of sexual harassment, she had no duty to investigate the complaint. When asked what she would do if she saw a female employee remove her clothes at a company outing, she indicated that it would depend on the circumstances.

(3) Also troubling is another HR representative's clear lack of understanding of sexual harassment. Following a training session, she had dinner with Senior Counsel Turner. While walking her to her car, he attempted to grab her. When she asked him what he was doing, he apologized. She then testified that Mr. Turner's actions did not violate The Service Company's sexual harassment policy.

(4) The Service Company's own Vice President of HR was unfamiliar with the sexual harassment complaint process as it was actually practiced at The Service Company. Thus, those individuals whose responsibilities should have included a thorough knowledge of how the company's sexual-harassment-related policies, procedures, and practices were implemented remained ignorant of the actual process.

(5) The company's policies and procedures included no instructions concerning documentation, record-keeping, or investigatory procedures. In fact, keeping records and documentation was not the norm at The Service Company. For example, General Counsel Brown (recall that he is the top legal representative for the company) noted that he made a habit of not taking notes when investigating a complaint of sexual harassment. He further specified that the determination of who should conduct an investigation related to a sexual harassment complaint was done on an ad hoc basis and that it was not the practice at The Service Company to memorialize the assessment of investigators in writing.

(6) Many employees charged with investigating complaints of sexual harassment were unaware of whether The Service Company's sexual harassment policy required documentation of complaints and investigations. For example, two HR representatives who were asked frequently to investigate complaints of sexual harassment indicated that they did not know if a policy existed that indicated complaints should be documented. When one of the representatives was asked if it was her practice to document incidents of sexual harassment, she stated that it depended on the incident.

(7) Additionally, no guidelines existed to assist managers in determining whether they should involve The Service Company's HR Department when investigating sexual harassment complaints. The Director of Employee Relations indicated that the company had no protocol for documenting a complaint of sexual harassment. Further, sending documentation regarding complaints of sexual harassment to the HR department was not required.

(8) As no records of sexually harassing incidents traveled to a central location (or were even kept), The Service Company put itself in the position of having no means of identifying repeat offenders or detecting offices or departments that had significant or severe problems with sexual harassment. For example, one HR representative testified that a temporary female employee complained that a male manager continually asked her for dates, called her, often invaded her personal space, and generally made her feel uncomfortable. The HR representative's response was to "have a talk" with this manager. However, she did not create any record of the complaint or document what, if any, steps she took to remedy the situation. In this instance, a female employee was receiving a disquieting amount of attention from a male employee, a situation that often escalates (Cleveland and Kerst 1993; Fitzgerald and Shullman 1993; Lucero et al. 2006). The HR 
representative should have been required to record information regarding the investigation and any remedial action she may have taken. She should have also sent a copy of this information to a central location (e.g., the HR Department), so that both she and the HR Department could monitor the situation.

Hence, while the firm and its leadership had an affirmative obligation to assess the environment regarding sexual harassment and correct any problems uncovered, the lack of record-keeping made it possible for The Service Company to ignore sexually harassing incidents and therefore, perpetrators at all levels and in all locations nationwide were able to engage in sexually harassing acts with impunity. Moreover, even those incidents that were memorialized in writing could be in any number of places including files kept in the Employee Relations Department, the legal department, or field offices. These files are not cross-referenced or collected/stored in a central location (even at the local level, sexual harassment complaints are not filed centrally). General Counsel Brown also indicated that he did not know what documents/complaints were in the files of the HR Department versus those in the files of The Service Company's legal department.

The consolidation of sexual harassment complaints was especially important to The Service Company's ability to determine the probative value of this information for assessing the extent of sexual harassment at its locations nationwide. Hence, while The Service Company and its leaders denied every claim of sexual harassment specified in the complaint and denied that company employees were forced to work in a sexually hostile work environment, they purposefully developed and implemented a system that kept information concerning incidents of sexual harassment from traveling adequately to a central location, allowing the company to turn a blind eye to the sexually harassing behavior that occurred in its workplace. That is, no controls were in place that would have enabled the company to address repeated claims of sexual harassment or stem the development of a sexually hostile work environment.

Finally, The Service Company had no specific guidelines for meting out discipline to those found to have violated its sexual harassment policy. Further, its sexual harassment policy did not specify those characteristics of a harassing incident that should be considered when determining disciplinary action (for example, whether inappropriate touching was involved).

The Impact of Employee Beliefs and Perceptions on Policy Effectiveness If targets of sexual harassment experience negative outcomes (e.g., retaliation, somatic and psychological problems, deterioration of the work environment) when they make a report, they are unlikely to have high expectations for relief and resolution. Additionally, such negative outcomes are likely to deter future reports of sexual harassment. Outcome expectancies for targets of sexual harassment are influenced largely by reporting process outcomes and the severity of sexual harassment (Knapp et al. 1997). Therefore, reporting even the most egregious offenses is unlikely to occur.

At The Service Company, Executive Vice President Jones circulated a memo to all employees indicating that if any person (e.g., friend, acquaintance, client) made inquiries concerning the lawsuit, employees should respond by indicating that: (1) the company had a zero tolerance policy regarding sexual harassment; (2) they had no knowledge of the facts of the case; and (3) the company intended to vigorously defend itself against the charges. Interestingly, nowhere in The Service Company's sexual harassment policy did the phrase 
"zero tolerance policy" exist, in spite of Mr. Jones's insistence that this statement was in the company's policy and procedures manual. Even more problematic was that Mr. Jones's memorandum instructed employees to tell anyone who asked that they had no knowledge of the facts relating to the lawsuit, even though many employees may have possessed this knowledge. When a company executive directs employees to be uncooperative or to prevaricate concerning sexually harassing incidents, it can have a chilling effect on employees' willingness to divulge pertinent information they have regarding such behavior.

A successful sexual harassment policy leads to the effective and timely resolution of target complaints (e.g., the sexual harassment is halted and retaliation does not occur). Based on the extant testimony, this did not occur at The Service Company. In fact, the results of The Service Company's policies were counterproductive: targets who reported an incident were likely to experience retaliation and/or receive no resolution to their complaints. Again, this increased the probability that future acts of sexual harassment would go unreported.

\section{Sexual Harassment Training}

The individual and organizational costs of sexual harassment highlight the need for effective training interventions that supplement sexual harassment policies and procedures. Training interventions alone are unlikely to produce increased reporting or decreased incidents of sexual harassment, especially if they exist within an organizational climate that lacks effective sexual harassment policies, does not enforce them, or that targets find threatening. However, training can play an important role in an organization's approach to sexual harassment prevention.

As indicated previously, The Service Company's training efforts were subpar, given intermittently, and not taken seriously by participants. Further, the Director of HR testified that sexual harassment training was performed on an ad hoc basis.

A female support staff employee indicated that a portion of the training was delivered on videotape. She described the session as a "free-for-all" in which male employees (including her boss) poked fun at the person in the video (a male) and made inappropriate comments. Hence, attendees of the session were engaging in sexually harassing behavior while watching a training video on sexual harassment.

Another female employee attended a mandatory training session on diversity (which included some elements related to sexual harassment). At dinner the night before the training, several male employees were joking that this was the last chance to have sex at a company outing. Later that evening, several male employees broke into the indoor pool and swam in the nude. They shouted at female guests, asking if they would like to remove their clothes and join them.

Clearly, for sexual harassment training to be effective, it must be taken seriously by the organizational leadership and employees. Obviously, the aforementioned employees believed that the training was not important to the company and did not feel compelled (by their leadership or by any other motive) to take the training seriously or in many cases, even attend the training. Moreover, The Service Company provided no training for employees charged with investigating sexual harassment complaints. This is especially problematic as neither The Service Company's HR Department nor its Legal Department provided instructions on how to properly conduct sexual harassment investigations. For example, General Counsel Brown stated that (a) no protocol existed for interviewing either targets or perpetrators; (b) no standard interview questions were provided for potential investigators; and (c) no direction was 
provided regarding the compilation of a complete and accurate history of the involvement of all parties in the reported incidents.

The experience of HR representative Judy provides a compelling example of why training for investigators is important. Judy witnessed one of her reportees, Isabelle, being touched inappropriately by a male manager, who later denied the allegation. Judy placed a disciplinary memo concerning the incident in both Isabelle's and the manager's personnel files. Judy indicated that she placed a memo in Isabelle's file because Isabelle did not report the incident to her. Had Judy been properly trained to conduct sexual harassment investigations, she would have known that most targets of sexual harassment do not formally report the behavior. She would have also learned that many targets "go-along" with the behavior or treat it as a joke because they fear retaliation or other negative consequences. Thus, Judy's implicit assumption that targets feel sufficiently safe in reporting incidents of sexual harassment was incorrect. Hence, the fact that Isabelle did not report the incident was not a valid reason for placing a disciplinary memorandum in her file.

Another example of The Service Company's need to properly train sexual harassment investigators is General Counsel Brown's assertion that incidents of sexual harassment in which the perpetrator denies the allegation required no further investigation. For example, when asked if he had disciplined one of the male managers for any of the sexually harassing conduct alleged in this complaint, he responded that because the manager denied the allegations, no discipline was indicated.

Another example of the impact of Mr. Brown's lack of training was his predilection for dismissing as fabrications incidents in which there were multiple accounts of the event. Consider the complaint of Janet. Janet drove an inebriated male manager, Tom, to his home after they attended a company function. Mr. Brown recounted that Janet complained to him that Tom fondled her while she was driving. When Mr. Brown met with Tom about the incident, he recounted that Tom stated he was intoxicated, and did not recall engaging in any illicit behavior. He further stated that he did not believe anything untoward occurred. Mr. Brown spoke with another female employee concerning the incident, and she indicated that Janet told her that when she and Tom arrived at Tom's residence, Tom pinned Janet against the wall and asked her to stay. Mr. Brown believed that because he heard "conflicting" accounts (that of Janet and the other female employee) and even though both accounts involved unwanted and inappropriate physical contact, no further investigation was necessary (he also did not consider that both of the described incidents may have occurred). Owing to this assumption (and because Tom was inebriated and could not remember what happened), General Counsel Brown concluded that Janet must have fabricated the incident (once again, Mr. Brown did not document any of his interviews).

This approach to investigation belies common sense in that Mr. Brown relied upon the expectation that a perpetrator would admit to acts of sexual harassment and hence, if an accused perpetrator denied the allegation, no further investigation was required. This expectation created an environment in which perpetrators knew that they merely had to deny an allegation of sexual harassment and the complaint would disappear. Particularly disturbing is the fact that while Mr. Brown held the highest position of any employee charged with the investigation of sexual harassment complaints, he lacked the knowledge and training required to properly conduct investigations. There was certainly no indication that he or anyone else at The Service Company made a commitment to conduct the type of investigations necessary to end the widespread harassment of women at The Service Company. 
Targeted Training Interventions As previously noted, the coping strategy a target chooses may be influenced by work group characteristics. For example, when work groups are comprised predominantly of one gender, targets are likely to choose a less effective response to sexual harassment. Unfortunately, organizations cannot readily change the gender composition of their workgroups, ${ }^{3}$ but they can monitor the climate of those work groups and offer training programs targeted to their unique needs. Training targeted to these groups should (a) raise employee awareness of the increased potential for sexual harassment within the workgroups, and (b) provide information about the effectiveness of the range of responses that are likely to end the harassment (e.g., confronting the perpetrator).

Another group for targeted training efforts includes those employees whose individual characteristics and power levels make them vulnerable to sexual harassment or are more likely to choose an ineffective response to sexual harassment. These individuals have a heightened need to understand the range of potential responses to sexual harassment and their relative effectiveness, as well as a thorough understanding of the range of reporting and dispute resolution options available to them.

The identification and training of those at risk for engaging in acts of sexual harassment is an essential element of effective training. Proclivities to sexually harass may be assessed by the Likelihood to Sexually Harass (LSH) scale developed by Pryor (1987) to evaluate an individual's propensity to engage in acts of sexual harassment. The scale has found significant support as a reliable and valid instrument (e.g., Krings and Facchin 2009; Lee et al. 2009) and may identify those individuals likely to engage in acts of sexual harassment and target them as potential candidates for training.

Finally, general training efforts for all employees that address employee rights and responsibilities related to sexual harassment and that explain the details of the organization's sexualharassment-related policies and procedures are important to the successful prevention of sexual harassment. Further, research indicates that comprehensive training efforts are necessary to affect a change in an organization's climate regarding sexual harassment (Hunter-Williams et al. 1999).

\section{Discussion}

The evidence in this case indicates that The Service Company's climate was clearly characterized as not only tolerant of sexual harassment, but in fact, was polluted with the sexual harassment of women that was both severe and pervasive. In addition, the physical layout of The Service Company's offices (most employees did not work in offices but had desks arranged in cubicles) made it impossible to avoid either seeing, hearing, or being subjected to acts of sexual harassment.

Moreover, the organization's leadership was instrumental in maintaining an environment tolerant of sexual harassment either by errors of omission (e.g., not taking reports seriously,

\footnotetext{
${ }^{3}$ This is not to suggest that the goal of a more gender-balanced workforce is not a desirable one. In fact, the research indicates that gender-balanced work groups are far less plagued by all of manner of sexually harassing behaviors. However, the implementation of plans to diversify is generally a long-term effort and an organization serious about eliminating sexual harassment must take intermediary steps in order to eradicate such behaviors in a timely manner.
} 
allowing retaliation against targets) or by errors of commission - that is, actually participating in the sexually harassing behavior. As previously discussed, the academic literature on sexual harassment is replete with studies that indicate an organization's climate has a significant impact on the degree of sexual harassment. Organizational climates tolerant of sexual harassment contribute to the frequency and severity of sexually harassing incidents and place a chilling effect on targets' reporting behavior.

The Service Company also failed to adhere to essential elements that are characteristic of best practices sexual harassment policies. In fact, based on my analysis of its policies and procedures (and their implementation), The Service Company violated virtually all of the elements of best practices sexual harassment policies and those violations resulted in severe harm to targets and allowed perpetrators to harass female employees with virtual impunity. The evidence also indicated that in practice, the policies and procedures at The Service Company were ineffective in stopping retaliation against targets. Additionally, it failed to sanction perpetrators, protect the privacy of individuals involved in ongoing investigations, and most importantly, minimize the occurrence of sexual harassment. Moreover, with poor standards for record keeping, the leadership and management at the company undermined the ability of targets to see that repeat offenders were stopped and properly disciplined. Ultimately, the lack of documentation prevented the company from controlling the extent of sexual harassment in its organization.

While The Service Company attempted to train employees on issues related to sexual harassment, the training was given sporadically and not taken seriously, particularly by the men who attended (and often left) the training sessions. Hence, these training efforts, regardless of content, were largely unsuccessful. This could only have occurred with the tacit support of the leadership at The Service Company. Had the training been truly mandatory and a serious issue for the organization, the leadership would have conveyed that message with enough gravitas to ensure that employees would attend and take the training seriously. Finally, no training was provided to employees charged with investigating sexual harassment complaints.

An analysis of the academic literature (23 studies spanning 32 years) concerning the reporting behavior of sexual harassment targets when examined with the evidence in this case, powerfully demonstrates that the reporting rate of sexually harassing incidents at The Service Company was likely negligible compared to that of other organizations (see Table 1 for a summary of studies that analyzed responses to sexual harassment). According to the scientific evidence, anywhere from zero to $33 \%$ of targets actually make formal reports of sexual harassment, with a mean rate that hovers around $10 \%$. Based on the evidence I examined, the likely reporting rate of individuals at The Service Company fell in the low range of that found in the literature. Indeed, it is my opinion that most incidents of sexual harassment went unreported at The Service Company and that the comparatively limited number of official reports that did exist were indicative of an underlying, far-reaching, and pervasive problem.

In addition, The Service Company had no adequate recordkeeping policies in place. Nevertheless, two factors suggest that: (1) individuals who did report sexual harassment were often subjected to retaliation (the overriding reason for non-reporting); and (2) the climate at The Service Company was tolerant of sexual harassment, such that incidents of sexual harassment were common, went unpunished, and were engaged in by many individuals, including many in powerful leadership positions within the organization.

As The Service Company deliberately chose to avoid documenting sexual harassment complaints, the company allowed the sexual harassment of female employees to run 
unchecked throughout the organization. In fact, while The Service Company's leaders and managers had an affirmative obligation to both understand the true extent of the sexual harassment within their workplace and correct any problems uncovered, the company's flagrant lack of record-keeping served to encourage the existence of these problems. Hence, perpetrators at all organizational levels and in many Service Company locations nationwide were able to engage in sexually harassing acts with impunity. Moreover, even those incidents that were memorialized in writing were neither cross-referenced nor kept in a central location. As noted by Service Company General Counsel Brown, those few complaints that were documented could be stored in any number of locations.

Clearly, The Service Company did not attempt to prevent the widespread, systemic problem it had with sexual harassment as it purposefully had no effective policies, procedures, and practices in place to do so. Quite simply, had The Service Company fully documented and centrally processed incidents of sexual harassment, it would have been in a position to: (a) estimate the number of unreported incidents, and (b) identify where in the firm additional training and/or some other form of remedial action may have been required.

The leadership and management of The Service Company also exhibited a pattern of retaliation against targets of sexual harassment that complained about the behavior. Targets of sexual harassment indicated that if they made a complaint of sexual harassment and the perpetrators were informed of the complaint, the perpetrators often refused to communicate with them concerning work-related issues and many times refused to speak to them at all. More troublesome is the fact that many targets of sexual harassment that made formal complaints were terminated after the complaint was made. For example, three women, each of whom complained of repeated sexual harassment by coworkers or supervisors, were constructively terminated by The Service Company, demonstrating that the consequences of sexual harassment may include devastating financial costs to targets in addition to negative effects on health and well-being.

The Service Company's story should be a cautionary tale for organizations that find themselves in similar circumstances and treat blithely incidents of sexual harassment. In its settlement with plaintiffs, The Service Company had to pay millions in attorney fees, donations to women's groups, and damages to targets of sexual harassment.

The Service Company faced a Hobson's choice - have adequate, appropriately implemented policies in place and provide training that is taken seriously by all employees, or pay the price. It is my fervent hope that The Service Company's story will assist other organizations in averting the types of mistakes it made and avoid the egregious incidents of sexual harassment suffered by its employees.

\section{References}

Adams, J. W., Kottke, J. L., \& Padgitt, J. S. (1983). Sexual harassment of university students. Journal of College Student Personnel, 24, 484-490.

Balogh, D. W., Kite, M. E., Pickel, K. L., Canel, D., \& Schroeder, J. (2003). The effects of delayed report and motive for reporting on perceptions of sexual harassment. Sex Roles, 48(7/8), 337-348.

Bastian, L. D., Lancaster, A. R., \& Reyst, H. E. (1996). Department of Defense 1995 Sexual Harassment Survey (DMDC Report No. 96-014). Arlington: Defense Manpower Data Center, Survey \& Program Evaluation Division.

Bell, M. E., \& Reardon, A. (2011). Experiences of sexual harassment and sexual assault in the military among OEF/OIF veterans: implications for health care providers. Social Work in Health Care, 50, 34-50. 
Berdahl, J. L. (2007a). Harassment based on sex: protecting social status in the context of gender hierarchy. Academy of Management Review, 32, 641-658.

Berdahl, J. L. (2007b). The sexual harassment of uppity women. Journal of Applied Psychology, 92, 425-437.

Berdahl, J. L., \& Moore, C. (2006). Workplace harassment: double jeopardy for minority women. Journal of Applied Psychology, 91, 426-436.

Bergman, B. (2008). Polarized gender thinking - visions or norms in male-dominated workplaces? International Journal of Qualitative Studies on Health and Well-Being, 3, 165-175.

Bergman, M. E., Langhout, R. D., Palmieri, P. A., Cortina, L. M., \& Fitzgerald, L. F. (2002). The (un)reasonableness of reporting: antecedents and consequences of reporting sexual harassment. Journal of Applied Psychology, 87(2), 230-242.

Bitton, M., \& Ben Shaul, D. (2013). Perceptions and attitudes to sexual harassment: an examination of sex differences and the sex composition of the harasser-target dyad. Journal of Applied Social Psychology, 43, 2136-2145.

Bobelian, M. (2004). Morgan Stanley settles discrimination suit for \$54 million. New York Law Journal, 8(1). http://www.newyorklawjournal.com. Accessed 24 Jan 2015.

Bowes-Sperry, L., \& O’Leary-Kelly, A. M. (2005). To act or not to act: the dilemma faced by sexual harassment observers. Academy of Management Review, 30, 288-306.

Brooks, L., \& Perot, A. R. (1991). Reporting sexual harassment: exploring a predictive model. Psychology of Women Quarterly, 15, 31-57.

Cleveland, J., \& Kerst, M. (1993). Sexual harassment and perceptions of power: an under-articulated relationship. Journal of Vocational Behavior, 42, 49-67.

Cochran, C. C., Frazier, P. A., \& Olson, A. M. (1997). Predictors of responses to unwanted sexual attention. Psychology of Women Quarterly, 21, 207-226.

Cortina, L. M., \& Wasti, S. A. (2005). Profiles in coping: responses to sexual harassment across persons, organizations, and cultures. Journal of Applied Psychology, 90, 182-192.

Cortina, L. M., Fitzgerald, L. F., \& Drasgow, F. (2002). Contextualizing Latina experiences of sexual harassment: preliminary tests of a structural model. Basic and Applied Social Psychology, 24(4), 295-311.

Cummings, B., \& Cohen, A. (2002). A slow fix. Sales and Marketing Management, 154(2), 14.

Dandekar, N. (1990). Contrasting consequences: bringing charges of sexual harassment compared with other cases of whistle-blowing. Journal of Business Ethics, 9, 151-158.

Defense Manpower Data Center (2013). 2012 Workplace and Gender Relations Survey of Active Duty Members: Survey Note and Briefing. (DMDC Note No. 2013-007). Arlington, VA: Author.

DuBois, C. L. Z., Kustis, G. A., Faley, R. H., \& Knapp, D. E. (1999). Perceptions of organizational responses to formal sexual harassment complaints. Journal of Managerial Issues, 11(2), 198-212.

Equal Employment Opportunity Commission. (1998). Compliance Manual. Riverwoods: CCH, Inc.

Equal Employment Opportunity Commission (2015a). Sexual Harassment Charges EEOC \& FEPAs Combined: FY 1997 - FY 2011. http:/www.eeoc.gov/eeoc/statistics/enforcement/sexual harassment.cfm. Accessed 3 Feb 2015.

Equal Employment Opportunity Commission (2015b). Sexual Harassment Charges FY 2010 - FY 2013. http:// www.eeoc.gov/eeoc/statistics/enforcement/sexual_harassment_new.cfm. Accessed 3 Feb 2015.

Faley, R. H., Knapp, D. E., Kustis, G. A., \& DuBois, C. L. Z. (1999). Estimating the organizational costs of sexual harassment: the case of the U.S. Army. Journal of Business and Psychology, 13(4), 461-484.

Firestone, J. M., \& Harris, R. J. (2003). Perceptions of effectiveness of responses to sexual harassment in the US military, 1988 and 1995. Gender, Work and Organization, 10(1), 42-64.

Fitzgerald, L. F., \& Shullman, S. L. (1993). Sexual harassment: a research analysis and agenda for the 1990s. Journal of Vocational Behavior, 42, 5-27.

Fitzgerald, L. F., Shullman, S. L., Bailey, N., Richards, M., Swecker, J., Gold, Y., Ormerod, M., \& Weitzman, L. (1988). The incidence and dimensions of sexual harassment in academia and the workplace. Journal of Vocational Behavior, 32, 152-175.

Fitzgerald, L. F., Swan, S., \& Fischer. (1995). Why didn't she just report him? The psychological and legal implications of women's responses. Journal of Social Issues, 51(1), 117-138.

Fitzgerald, L. F., Drasgow, F., Hulin, C. L., Gelfand, M. J., \& Magley, V. J. (1997). Antecedents and consequences of sexual harassment in organizations: a test of an integrated model. Journal of Applied Psychology, 82, 578-589.

Gadlin, H. (1991). Careful maneuvers: mediating sexual harassment. Negotiation Journal, 7, 139-153.

Gettman, H. J., \& Gelfand, M. J. (2007). When the customer shouldn't be king: antecedents and consequences of sexual harassment by clients and customers. Journal of Applied Psychology, 92, 757-770.

Grauerholz, E. (1989). Sexual harassment of women professors by students: exploring the dynamics of power, authority, and gender in a university setting. Sex Roles, 21, 789-801.

Gruber, J. E. (1989). How women handle sexual harassment: a literature review. Sociology and Social Research, 74, 3-9. 
Gruber, J. E., \& Bjorn, L. (1982). Blue-collar blues: the sexual harassment of women autoworkers. Work and Occupations, 9, 271-298.

Gruber, J. E., \& Smith, M. D. (1995). Women's responses to sexual harassment: a multivariate analysis. Basic and Applied Social Psychology, 17(4), 543-562.

Gutek, B. A. (1985). Sex and the workplace: Impact of sexual behavior and harassment on women, men, and organizations. San Francisco: Jossey-Bass.

Gutek, B. A., Cohen, A. G., \& Konrad, A. M. (1990). Predicting social-sexual behavior at work: a contact hypothesis. Academy of Management Journal, 33, 560-577.

Gutek, B. A., \& Koss, M. P. (1993). Changed women and changed organizations: consequences of and coping with sexual harassment. Journal of Vocational Behavior, 42, 28-48.

Gutek, B. A., \& Nakamura, C. Y. (1982). Gender roles and sexuality in the world of work. In E. R. Allgeier \& N. B. McCormick (Eds.), Changing boundaries: Gender roles and sexual behavior (pp. 182-201). San Francisco: Mayfield.

Halbesleben, J. R. B. (2009). The role of pluralistic ignorance in the reporting of sexual harassment. Basic and Applied Social Psychology, 31, 210-217.

Hershcovis, M. S., \& Barling, J. (2010). Comparing victim attributions and outcomes for workplace aggression and sexual harassment. Journal of Applied Psychology, 95, 874-888.

Hotelling, K. (1991). Sexual harassment: a problem shielded by silence. Journal of Counseling and Development, 69, 497-501.

Hulin, C. L., Fitzgerald, L. F. \& Drasgow, F. (1996). Organizational influences on sexual harassment. In M. Stockdale (Ed.), Sexual harassment in the workplace, Vol. 5 (pp. 127-150).

Hunter-Williams, J., Fitzgerald, L. F., \& Drasgow, F. (1999). The effects of organizational practices on sexual harassment and individual outcomes in the military. Military Psychology, 11(3), 303-328.

Jacobs, J. A., \& Kearns, C. N. (2001). Responding effectively to a claim of sexual harassment in the workplace. Association Management, 53(11), 18-19.

Jenson v. Eveleth Taconite Co., 139 F.R.D. 657 (D. Minn. 1991).

Kanter, R. M. (1977). Some effects of proportions on group life: skewed sex ratios and responses to token women. American Journal of Sociology, 82, 965-990.

Kessler, G. R. (2001). Adequate sexual harassment policies for the productive workplace. Employee Rights Quarterly, 2(2), 32-39.

Knapp, D. E., Faley, R. H., Ekeberg, S. E., \& Dubois, C. L. Z. (1997). Determinants of target response to sexual harassment: a conceptual framework. Academy of Management Review, 22(1), $687-729$.

Koss, M. P. (1990). Changed lives: The psychological impact of sexual harassment. In M. Paludi (Ed.), Ivory power: Sexual harassment on campus (pp. 73-92). Albany: SUNY Press.

Kremer, J. M., \& Marks, J. (1992). Sexual harassment: the response of management and trade unions. Journal of Occupational and Organizational Psychology, 65(1), 5-15.

Krings, F., \& Facchin. (2009). Organizational justice and men's likelihood to sexually harass: the moderating role of sexism and personality. Journal of Applied Psychology, 94, 501-510.

Lach, D. H., \& Gwartney-Gibbs, P. A. (1993). Sociological perspectives on sexual harassment and workplace dispute resolution. Journal of Vocational Behavior, 42, 102-115.

Langhout, R. D., Bergman, M. E., Cortina, L. M., Fitzgerald, L. F., Drasgow, F., \& Hunter-Williams, J. (2005). Sexual harassment severity: assessing situational and personal determinants and outcomes. Journal of Applied Social Psychology, 35, 975-1007.

Lee, J. O., Welbourne, J. L., Hoke, W. A., \& Beggs, J. (2009). Examining the interaction among likelihood to sexually harass, ratee attractiveness, and job performance. Journal of Management, 35, 445-461.

Lim, S., \& Cortina, L. M. (2005). Interpersonal mistreatment in the workplace: the interface and impact of general incivility and sexual harassment. Journal of Applied Psychology, 90, 483-496.

Lipari, R. N., \& Lancaster, A. R. (2003). Armed Forces 2002 Sexual Harassment Survey (DMDC Report No. 2003-026). Arlington: Defense Manpower Data Center.

Lipari, R. N., Cook, P. M., Rock, L. M., \& Matos, K. (2008). 2006 Gender Relations Survey of Active Duty Members (DMDC Report No. 2007-022). Arlington: Defense Manpower Data Center.

Livingston, J. A. (1982). Responses to sexual harassment on the job: legal, organizational, and individual actions. Journal of Social Issues, 38(4), 5-22.

Los Angeles Commission on the Status of Women. (1992). Report on the City of Los Angeles 1992 Sexual Harassment Survey. Los Angeles: City of Los Angeles.

Lucero, M. A., Allen, R. E., \& Middleton, K. L. (2006). Sexual harassers: behaviors, motives, and change over time. Sex Roles, 55, 331-343.

Magley, V. J. (2002). Coping with sexual harassment: reconceptualizing women's resistance. Journal of Personality and Social Psychology, 83(4), 930-946. 
Malamut, A. B., \& Offermann, L. R. (2001). Coping with sexual harassment: personal, environment, and cognitive determinants. Journal of Applied Psychology, 86(6), 1152-1166.

Martindale, M. (1989). Sexual harassment in the military: 1988. Arlington: Defense Manpower Data Center.

Maypole, D. E. (1986). Sexual harassment of social workers at work: Injustice within? Social Work, 31, $29-34$.

Mellon, R. C. (2013). On the motivation of quid pro quo sexual harassment in men: relation to masculine gender role stress. Journal of Applied Social Psychology, 43, 2287-2296.

Near, J. P., Rehg, M. T., Van Scotter, J. R., \& Miceli, M. P. (2004). Does type of wrongdoing affect the whistleblowing process? Business Ethics Quarterly, 14(2), 219-242.

O'Farrell, B., \& Harlan, S. L. (1982). Craftworkers and clerks: the effects of male co-worker hostility on women's satisfaction with non-traditional jobs. Social Problems, 29, 252-264.

Offermann, L. R., \& Malamut, A. B. (2002). When leaders harass: the impact of target perceptions of organizational leadership and climate on harassment reporting and outcomes. Journal of Applied Psychology, 87(5), 885-893.

O’Leary-Kelly, A. M., Bowes-Sperry, L., Bates, C. A., \& Lean, E. R. (2009). Sexual harassment at work: a decade (plus) of progress. Journal of Management, 35, 503-536.

Pearce, J. A., II, \& DiLullo, S. A. (2001). A business policy statement model for eliminating sexual harassment and related employer liability. S.A.M Advanced Management Journal, 66(2), 12-21.

Peirce, E. R., Rosen, B., \& Hiller, T. B. (1997). Breaking the silence: creating user-friendly sexual harassment policies. Employee Responsibilities and Rights Journal, 10, 225-242.

Popovich, P. M. (1988). Sexual harassment in organizations. Employee Responsibilities and Rights Journal, 1 , 273-282.

Pryor, J. B. (1987). Sexual harassment proclivities in men. Sex Roles, 17, 269-89.

Rabinowitz, V. C. (1990). Coping with sexual harassment. In M. Paludi (Ed.), Ivory power: Sexual harassment on campus (pp. 103-118). Albany: SUNY Press.

Raver, J. L., \& Gelfand, M. J. (2005). Beyond the individual victim: linking sexual harassment, team processes, and team performance. Academy of Management Journal, 48, 387-400.

Raver, J. L., \& Nishii, L. H. (2010). Once, twice, or three times as harmful? Ethnic harassment, gender harassment, and generalized workplace harassment. Journal of Applied Psychology, 95, 236-254.

Remick, H., Salisbury, J., Stringer, D., \& Ginorio, A. (1990). Investigating complaints sexual harassment. In M. Paludi (Ed.), Ivory power: Sexual harassment on campus (pp. 191-212). Albany: SUNY Press.

Sandroff, R. (1988). Sexual harassment in the Fortune 500. Working Woman, 13(12), 69-73.

Sandroff, R., \& Baseman, G. (1992). Sexual harassment. Working Woman, 17(6), 47-51.

Schein, E. H. (1992). Organizational Culture and Leadership. San Francisco: Jossey-Bass.

Schneider, B. E. (1987). Graduate women, sexual harassment, and university policy. Journal of Higher Education, 58, 46-65.

Schneider, B. E. (1990). The climate for service: An application of the climate construct. In B. Schneider (Ed.), Organizational climate and culture (pp. 383-412). San Francisco: Jossey-Bass.

Sigal, J., Braden-Maguire, J., Patt, I., Goodrich, C., \& Perrino, C. S. (2003). Effects of type of coping response, setting, and social context on reactions to sexual harassment. Sex Roles, 48(3/4), 157-166.

Stockdale, M. S. (1998). The direct and moderating influences of sexual-harassment pervasiveness, coping strategies, and gender on work-related outcomes. Psychology of Women Quarterly, 22(4), 521-535.

Stokes, P. P., Stewart-Belle, S., \& Barnes, J. M. (2000). The supreme court holds class on sexual harassment: how to avoid a failing grade. Employee Responsibilities and Rights Journal, 12, 79-91.

U.S. Merit Systems Protection Board. (1981). Sexual harassment in the Federal workplace: Is it a problem? Washington: U.S. Government Printing Office.

U.S. Merit Systems Protection Board. (1988). Sexual harassment in the Federal government: An update. Washington: U.S. Government Printing Office.

U.S. Merit Systems Protection Board. (1995). Sexual harassment in the Federal workplace: Trends, progress, continuing challenges. Washington: U.S. Government Printing Office.

Watson, L. B., Ancis, J. R., White, D. N., \& Nazari, N. (2013). Racial identity buffers African American women from body image problems and disordered eating. Psychology of Women Quarterly, 37, 337-350.

Weiser, B. (1998). Brokerage settles sexual and racial bias suit. New York Times, April 9. Available: http://www. aol.com/nytcopy. Accessed 31 Dec 2013.

Welsh, \& Gruber, S. (1999). Not taking it anymore: women who report or file complaints of sexual harassment. Canadian Review of Sociology and Anthropology, 36(4), 559-583.

Willness, C. R., Steel, P., \& Lee, K. (2007). A meta-analysis of the antecedents and consequences of workplace sexual harassment. Personnel Psychology, 60, 127-162.

Wishnietsky, D. H. (1991). Reported and unreported teacher-student sexual harassment. Journal of Education Research, 84(3), 164-169.

Women's Legal Defense Fund (1991). Sexual harassment in the workplace. Washington, D.C. 